Supplementary Information for

\title{
Catalytic hydrazine disproportionation mediated by a thiolate-bridged VFe complex
}

\author{
Nina X. Gu, ${ }^{a}$ Gaël Ung, ${ }^{b}$ and Jonas C. Peters*a \\ ${ }^{a}$ Division of Chemistry and Chemical Engineering, California Institute of Technology, \\ Pasadena, California, 91125, United States \\ ${ }^{b}$ Department of Chemistry, University of Connecticut, Storrs, Connecticut, 06269, United States
}

*Email: jpeters@,caltech.edu

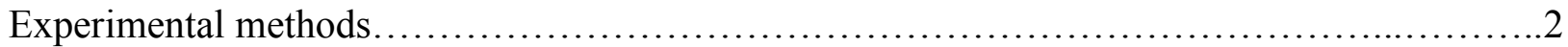

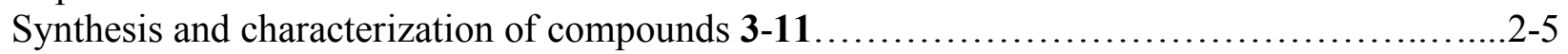

NMR spectra............................................................... 5-7

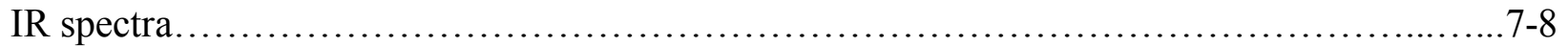

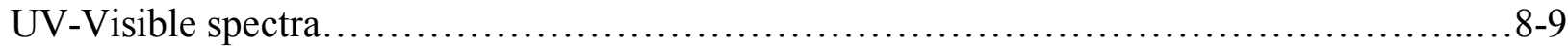

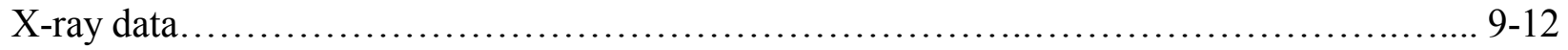

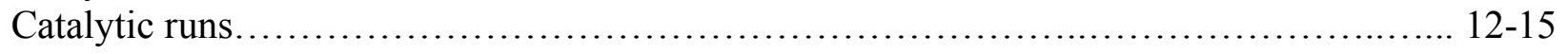

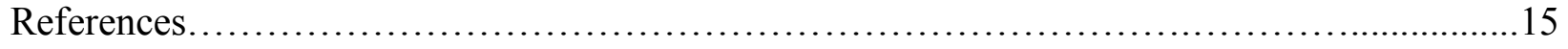


General considerations. All syntheses and measurements, unless otherwise stated, were carried out under an inert atmosphere $\left(\mathrm{N}_{2}\right)$ in a glovebox or using standard Schlenk techniques, and solvents were dried and degassed by thoroughly sparging with $\mathrm{N}_{2}$ and then passing through an activated alumina column in a solvent purification system supplied by SG Water, LLC. 2-

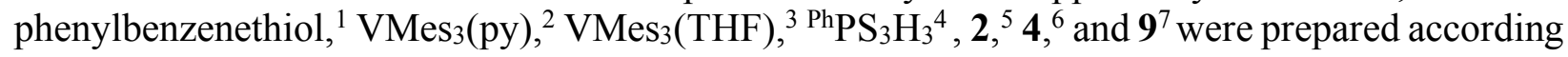
to literature procedures. All other reagents were purchased from commercial vendors and used without further purification unless otherwise stated.

Physical methods. NMR spectra $\left({ }^{1} \mathrm{H},{ }^{31} \mathrm{P}\right)$ were collected on Varian 300 or $400 \mathrm{MHz}$ spectrometers (25 ${ }^{\circ} \mathrm{C}$ unless otherwise specified). ${ }^{1} \mathrm{H}$ chemical shifts are reported in ppm, relative to tetramethylsilane using residual proton and ${ }^{31} \mathrm{P}$ chemical shifts are reported in ppm relative to $85 \%$ aqueous $\mathrm{H}_{3} \mathrm{PO}_{4}$. Thin film IR spectra were obtained using a Bruker Alpha Platinum ATR spectrometer with OPUS software in a glovebox under an $\mathrm{N}_{2}$ atmosphere. Optical spectroscopy measurements were taken on a Cary $50 \mathrm{UV}-\mathrm{V}$ is spectrophotometer using a $1 \mathrm{~cm}$ quartz cell, unless otherwise noted. Combustion analysis was carried out by either Midwest Microlabs (Indianapolis) or the Beckman Institute Crystallography Facility (Caltech). $\mathrm{H}_{2}$ was analyzed on an Agilent 7890A gas chromatograph (HP-PLOT U, $30 \mathrm{~m}, 0.32 \mathrm{~mm} \mathrm{ID;} 30^{\circ} \mathrm{C}$ isothermal; nitrogen carrier gas) using a thermal conductivity detector. Mass spectroscopy data for $\mathbf{5}$ and $\mathbf{6}$ were obtained using a Thermo LCQ ion trap mass spectrometer. High-resolution mass spectroscopy data for 7 was collected by direct infusion electrospray ionization in the positive ion mode using an LCT Premier XE time-offlight mass spectrometer (Waters).

$X$-ray crystallography. X-ray diffraction (XRD) measurements were carried out in the Beckman Institute Crystallography Facility. XRD measurements were collected using a dual source Bruker D8 Venture, four-circle diffractometer with a PHOTON CMOS detector. Structures were solved using SHELXT and refined against $F^{2}$ on all data by full-matrix least squares with SHELXL. The crystals were mounted on a glass fiber under Paratone $\mathrm{N}$ oil.

\section{Synthesis and characterization of 3-11.}

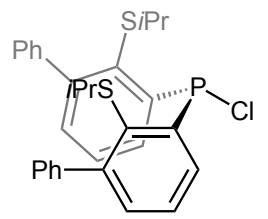

Chlorobis(2-(isopropylthio)-[1,1'-biphenyl]-3-yl)phosphine (3).

Neat $\mathrm{P}\left(\mathrm{NEt}_{2}\right) \mathrm{Cl}_{2}(1.3 \mathrm{~g}, 7.1 \mathrm{mmol})$ was added dropwise to a stirring suspension of $2(5.0 \mathrm{~g}, 14.3 \mathrm{mmol})$ in $\mathrm{Et}_{2} \mathrm{O}(100 \mathrm{~mL})$ at $-78^{\circ} \mathrm{C}$. The reaction was stirred overnight with slow warming to $25^{\circ} \mathrm{C}$. The volatiles were subsequently removed under reduced pressure, and the resulting solids were extracted with pentane ( 3 x $25 \mathrm{~mL})$, then dried and redissolved in $\mathrm{Et}_{2} \mathrm{O}(100 \mathrm{~mL}) . \mathrm{HCl}\left(2 \mathrm{M}\right.$ in $\left.\mathrm{Et}_{2} \mathrm{O}, 28.5 \mathrm{~mL}\right)$ was added dropwise to the stirring reaction mixture at $0{ }^{\circ} \mathrm{C}$, and the reaction was allowed to stir at $25{ }^{\circ} \mathrm{C}$ for $1 \mathrm{~h}$. The reaction volatiles were subsequently removed under reduced pressure, and the crude product was extracted from the mixture with pentane $(3 \times 50 \mathrm{~mL})$. The pentane solution was concentrated to $15 \mathrm{~mL}$ and chilled to $-78{ }^{\circ} \mathrm{C}$ to precipitate the product. The title compound was isolated by filtration as a white solid. The filtrate was collected, concentrated, and cooled to -78 ${ }^{\circ} \mathrm{C}$ to yield additional material $(1.94 \mathrm{~g}, 26 \%) .{ }^{1} \mathrm{H}$ NMR $\left(\mathrm{C}_{6} \mathrm{D}_{6}, 400 \mathrm{MHz}, 298 \mathrm{~K}, \delta\right): 7.81(\mathrm{~d}, J=$ $7.5 \mathrm{~Hz}, 2 \mathrm{H}), 7.40$ (d, $J=7.2 \mathrm{~Hz} 2 \mathrm{H}), 7.12-7.03(\mathrm{~m}, 16 \mathrm{H}), 2.84$ (hept, $J=7.0 \mathrm{~Hz}, 1 \mathrm{H}), 1.00$ (d, $J=$ $6.7 \mathrm{~Hz}, 6 \mathrm{H}), 0.84$ (d, J=6.8 Hz, 6H). ${ }^{31} \mathrm{P}$ NMR (C6 $\left.\mathrm{D}_{6}, 300 \mathrm{MHz}, 298 \mathrm{~K}, \delta\right): 49.81$ (s). 


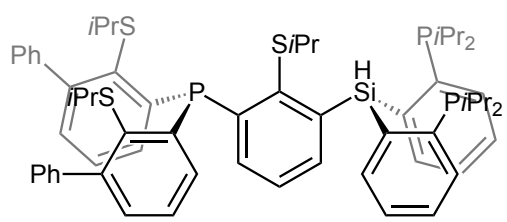

(((3-(bis(2-(isopropylthio)-[1,1'-biphenyl]-3-yl) phosphino)-2(isopropylthio)phenyl)silanediyl)bis(2,1phenylene))bis(diisopropylphosphine) (5).

$N$-BuLi (1.6 M in hexane, $0.9 \mathrm{~mL}, 1.4 \mathrm{mmol})$ was added dropwise to a stirring solution of $4(0.82 \mathrm{~g}, 1.3 \mathrm{mmol})$ in $\mathrm{Et}_{2} \mathrm{O}(20 \mathrm{~mL})$ at $78{ }^{\circ} \mathrm{C}$. The reaction was allowed to stir at $-78{ }^{\circ} \mathrm{C}$ for $1 \mathrm{~h}$ and subsequently allowed to stir at $25^{\circ} \mathrm{C}$ for $1 \mathrm{~h}$. The volatiles were removed under reduced pressure, and the resulting off-white solid was redissolved in toluene $(20 \mathrm{~mL})$. A cold solution of $3(0.66 \mathrm{~g}, 1.3 \mathrm{mmol})$ in toluene $(20 \mathrm{~mL})$ was added dropwise to the stirring reaction, and the reaction mixture was stirred overnight with slow warming to $25^{\circ} \mathrm{C}$. The volatiles were subsequently removed in vacuo. The resulting residue was redissolved in $\mathrm{Et}_{2} \mathrm{O}(20 \mathrm{~mL})$ and filtered through Celite. The filtrate was concentrated to yield the title compound as an off-white solid $(1.10 \mathrm{~g}, 82 \%)$. The title compound can be recrystallized from a concentrated pentane solution at $25^{\circ} \mathrm{C} .{ }^{1} \mathrm{H}$ NMR $\left(\mathrm{C}_{6} \mathrm{D}_{6}, 400 \mathrm{MHz}, 298 \mathrm{~K}, \delta\right): 7.52(\mathrm{dd}, J=17.5$, $7.4 \mathrm{~Hz}, 4 \mathrm{H}), 7.41$ (t, $J=8.6 \mathrm{~Hz}, 2 \mathrm{H}), 7.36-7.02(\mathrm{~m}, 20 \mathrm{H}), 6.96$ (t, $J=7.4 \mathrm{~Hz}, 1 \mathrm{H}), 4.59$ (bs, $1 \mathrm{H})$, 3.31 (hept, 1H), 3.10 (hept, 1H), $2.20-1.89$ (m, 4H), 1.52 (d, $J=6.8 \mathrm{~Hz}, 6 \mathrm{H}), 1.36-1.25$ (m, $3 \mathrm{H}), 1.25-0.94(\mathrm{~m}, 21 \mathrm{H}), 0.90-0.79(\mathrm{~m}, 12 \mathrm{H}) .{ }^{31} \mathrm{P}$ NMR $\left(\mathrm{C}_{6} \mathrm{D}_{6}, 300 \mathrm{MHz}, 298 \mathrm{~K}, \delta\right): 2.12(\mathrm{~s})$, 1.84 (s), -17.00 (s). ESI-MS (positive ion, amu): Calcd. 1089.4 ([M-Na $]^{+}$); Found. 1089.2.

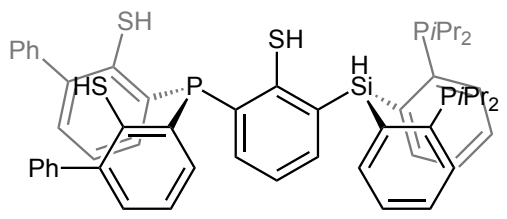

\section{3,3"-((3-(bis(2-(diisopropylphosphino)phenyl)silyl)-2- mercaptophenyl)phosphinediyl)bis(([1,1'-biphenyl]-2- thiol)) (6).}

A suspension of $\mathrm{KC}_{8}(0.470 \mathrm{~g}, 3.5 \mathrm{mmol})$ in THF $(15 \mathrm{~mL})$ was added dropwise to a stirring solution of $5(1.108 \mathrm{~g}, 1.05 \mathrm{mmol})$ in THF $(50 \mathrm{~mL})$ at $-78^{\circ} \mathrm{C}$. The reaction was stirred at $25^{\circ} \mathrm{C}$ for $1 \mathrm{~h}$ to yield a deep red solution. The reaction mixture was filtered to remove graphite, and solid pyridinium chloride $(0.670 \mathrm{~g}, 5.8$ $\mathrm{mmol}$ ) was added at $25^{\circ} \mathrm{C}$ to the stirring solution. The color of the reaction mixture changed from deep red to pale yellow during the addition of acid. The reaction was stirred at $25^{\circ} \mathrm{C}$ for $1 \mathrm{~h}$, and the volatiles were subsequently removed in vacuo. The product was extracted from the remaining white solid with pentane $(3 \times 25 \mathrm{~mL})$, and the volatiles were removed under reduced pressure to afford the title compound as an off-white solid and used as is $(0.803 \mathrm{~g}, 82 \%) .{ }^{1} \mathrm{H} N M R\left(\mathrm{C}_{6} \mathrm{D}_{6}, 300\right.$ MHz, $298 \mathrm{~K}, \delta): 7.43-7.01(\mathrm{~m}, 19 \mathrm{H}), 6.91(\mathrm{t}, J=7.6 \mathrm{~Hz}, 5 \mathrm{H}), 6.83$ (t, $J=7.4 \mathrm{~Hz}, 3 \mathrm{H}), 4.72$ (d, $J$ $=3.7 \mathrm{~Hz}, 2 \mathrm{H}), 4.65(\mathrm{bs}, 1 \mathrm{H}), 2.06-1.88(\mathrm{~m}, 4 \mathrm{H}), 1.09(\mathrm{ddd}, J=14.4,9.4,6.9 \mathrm{~Hz}, 12 \mathrm{H}), 0.93(\mathrm{dd}$, $J=12.0,7.1 \mathrm{~Hz}, 6 \mathrm{H}), 0.86(\mathrm{dd}, J=11.7,7.2 \mathrm{~Hz}, 6 \mathrm{H}) .{ }^{31} \mathrm{P}$ NMR $\left(\mathrm{C}_{6} \mathrm{D}_{6}, 162 \mathrm{MHz}, 298 \mathrm{~K}, \delta\right): 0.95$ (s), -24.15 (s). ESI-MS (positive ion, amu): Calcd. $925.3\left([\mathrm{M}-\mathrm{H}]^{+}\right)$; Found. 925.0.

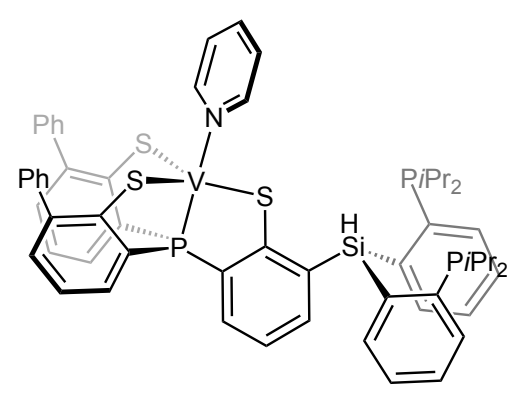
precipitate additional material $(0.125 \mathrm{~g}, 29 \%)$. Yellow-orange crystals suitable for XRD were grown from slow diffusion of pentane into a concentrated THF solution at $25^{\circ} \mathrm{C} .{ }^{1} \mathrm{H}$ and ${ }^{31} \mathrm{P}$ NMR

V-(SAr) (7)

A solution of $\mathrm{VMes}_{3}(\mathrm{py})(0.218 \mathrm{~g}, 0.45 \mathrm{mmol})$ and pyridine $(0.1$ $\mathrm{mL})$ in THF $(10 \mathrm{~mL})$ was added dropwise to a stirring solution of $6(0.376 \mathrm{~g}, 0.41 \mathrm{mmol})$ in THF at $25^{\circ} \mathrm{C}$. The reaction mixture was stirred for $5 \mathrm{~h}$ at $25^{\circ} \mathrm{C}$, and the volatiles were subsequently removed in vacuo to yield a dark yellow-brown residue. The resulting solids were washed with THF $(3 \times 5 \mathrm{~mL})$ to yield the title compound as a yellow-orange solid. The filtrate was concentrated and pentane was allowed to slowly diffuse onto the solution to 
in $\mathrm{C}_{6} \mathrm{D}_{6}$ at $25{ }^{\circ} \mathrm{C}$ were silent. $\mu_{\mathrm{eff}}$ (THF, Evans method, $298 \mathrm{~K}$ ): 3.3 $\mu_{\mathrm{B}}$. Anal. Calcd. for $\mathrm{C}_{59} \mathrm{H}_{61} \mathrm{NP}_{3} \mathrm{~S}_{3} \mathrm{SiV}$ : C, 67.34; H, 5.84; N, 1.33. Found: C, 66.52, H, 6.00; N, 1.23. UV-vis (THF, $\left.298 \mathrm{~K}, \mathrm{~nm}\left\{\mathrm{~cm}^{-1} \mathrm{M}^{-1}\right\}\right): 462$ \{3600\}. ESI-MS (positive ion, amu): Calc $\left(\mathrm{M}^{+}\right)$: 1051.2388, Found: 1051.2361 .

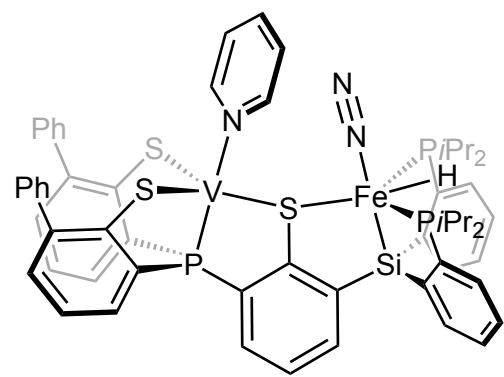

\section{$\mathrm{V}-(\boldsymbol{\mu}-\mathrm{SAr})-\mathrm{Fe}\left(\mathrm{N}_{2}\right)(\mathbf{H})(\mathbf{8})$}

A solution of 7 (44.9 $\mathrm{mg}, 0.043 \mathrm{mmol})$ in THF $(10 \mathrm{~mL})$ was added to solid $\mathrm{FeBr}_{2}(10.1 \mathrm{mg}, 0.047 \mathrm{mmol})$ and stirred at $25^{\circ} \mathrm{C}$ for $1 \mathrm{~h}$ to yield an orange solution. The volatiles were subsequently removed under reduced pressure, and the remaining orange solid was suspended in $\mathrm{Et}_{2} \mathrm{O}(5 \mathrm{~mL})$ and allowed to stir for $10 \mathrm{~min}$ at 23 ${ }^{\circ} \mathrm{C}$. The volatiles were removed in vacuo, and the resulting dark orange solid was dissolved in $10 \mathrm{~mL}$ of benzene and added to $\mathrm{Na}(\mathrm{Hg})$ amalgam $(2.1 \mathrm{mg}$ of $\mathrm{Na}, 0.091 \mathrm{mmol})$. The reaction was allowed to vigorously stir at 25 ${ }^{\circ} \mathrm{C}$ for $2 \mathrm{~h}$, which yielded a dark orange-brown solution. The solution was filtered through Celite and lyophilized. The resulting material was washed with pentane $(3 \times 5 \mathrm{~mL})$ and extracted with diethyl ether $(10 \mathrm{~mL})$ to afford the title complex as a dark orange-brown solid $(26.7 \mathrm{mg}, 55 \%$ yield). Dark orange-brown crystals were grown from slow concentration of a solution of 8 ( $3 \mathrm{~mL}$ $\mathrm{Et}_{2} \mathrm{O}$ with $c a .100 \mu \mathrm{L}$ pyridine) at $-35^{\circ} \mathrm{C}$. ${ }^{1} \mathrm{H}$ and ${ }^{31} \mathrm{P}$ NMR in $\mathrm{C}_{6} \mathrm{D}_{6}$ at $25{ }^{\circ} \mathrm{C}$ were silent. $\mu_{\text {eff }}\left(\mathrm{C}_{6} \mathrm{D}_{6}\right.$, Evans method, $298 \mathrm{~K}$ ): $3.1 \mu_{\mathrm{B}}$. $\mu_{\text {eff }}$ (toluene- $d 8$, Evans method, $223 \mathrm{~K}$ ): $3.3 \mu_{\mathrm{B}}$. Anal. Calcd. for $\mathrm{C}_{59} \mathrm{H}_{61} \mathrm{FeN}_{3} \mathrm{P}_{3} \mathrm{~S}_{3} \mathrm{SiV}$ : C, 62.37; H, 5.41; N, 3.70. Found: C, 62.58; H, 5.45; N, 1.73 (Note: low nitrogen content may be due to lability of the coordinated $\left.\mathrm{N}_{2}\right)$. UV-vis (THF, $298 \mathrm{~K}, \mathrm{~nm}\left\{\mathrm{~cm}^{-1} \mathrm{M}^{-}\right.$ $\left.\left.{ }^{1}\right\}\right): 446\{5100\}, 613\{2700\}, 726\{2600\}$. IR (solid, $\left.\mathrm{cm}^{-1}\right): 2054\left(\mathrm{~N}_{2}\right), 1898(\mathrm{Fe}-\mathrm{H})$.

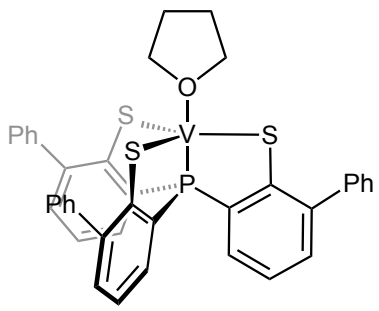

\section{$\mathrm{PhPS}_{3} \mathrm{~V}$ (THF).}

A solution of $\mathrm{VMes}_{3}(\mathrm{THF})(30.1 \mathrm{mg}, 0.063 \mathrm{mmol})$ in THF $(5 \mathrm{~mL})$ was

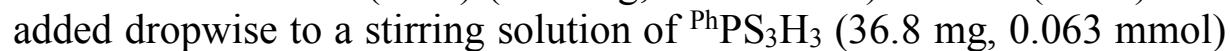
in THF $(5 \mathrm{~mL})$ at $25^{\circ} \mathrm{C}$. The reaction was stirred for $2 \mathrm{~h}$, and the volatiles were subsequently removed in vacuo. The resulting yellow-brown solid was washed with pentane $(3 \times 5 \mathrm{~mL})$ and $\mathrm{Et}_{2} \mathrm{O}(5 \mathrm{~mL})$. The solids were dissolved in THF and filtered through Celite. The solution was concentrated to yield the product as a yellow-orange solid (35.0 mg, 79.0\% yield). The product was recrystallized in a THF/pentane vapor diffusion cell at $25^{\circ} \mathrm{C}$, which yielded yellow-orange crystals suitable for XRD. ${ }^{1} \mathrm{H}$ and ${ }^{31} \mathrm{P}$ NMR in $\mathrm{C}_{6} \mathrm{D}_{6}$ at $25^{\circ} \mathrm{C}$ were silent. $\mu_{\text {eff }}\left(\mathrm{C}_{6} \mathrm{D}_{6}\right.$, Evans method, $298 \mathrm{~K}): 2.6 \mu_{\mathrm{B}}$. Anal. Calcd. for $\mathrm{C}_{40} \mathrm{H}_{32} \mathrm{OPS}_{3} \mathrm{~V}: \mathrm{C}, 67.97 ; \mathrm{H}, 4.56 ; \mathrm{N}, 0.00$. Found: C, 68.04; H, 4.88; N, -0.08. UV-vis (THF, $\left.298 \mathrm{~K}, \mathrm{~nm}\left\{\mathrm{~cm}^{-1} \mathrm{M}^{-1}\right\}\right): 462\{3800\}$.

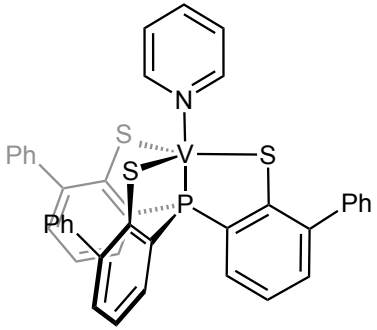

\section{${ }^{P_{P}} \mathbf{P S}_{3} \mathrm{~V}$ (py) (11).}

Pyridine $(\mathrm{ca} .100 \mu \mathrm{L})$ was added to a solution of ${ }^{\mathrm{PhPS}} \mathrm{P}_{3} \mathrm{~V}(\mathrm{THF})(0.040 \mathrm{~g}$, $0.056 \mathrm{mmol})$ in benzene $(10 \mathrm{~mL})$ and stirred at $25{ }^{\circ} \mathrm{C}$ overnight. The reaction mixture was lyophilized to yield the title compound as a yelloworange solid. The product was recrystallized in a $\mathrm{C}_{6} \mathrm{H}_{6} /$ pentane vapor diffusion cell at $25^{\circ} \mathrm{C}$, which yielded yellow-orange crystals suitable for XRD. ${ }^{1} \mathrm{H}$ and ${ }^{31} \mathrm{P} N M R$ in $\mathrm{C}_{6} \mathrm{D}_{6}$ at $25{ }^{\circ} \mathrm{C}$ were silent. $\mu_{\text {eff }}\left(\mathrm{C}_{6} \mathrm{D}_{6}\right.$, Evans method, $298 \mathrm{~K}$ ): $2.4 \mu_{\text {B }}$. Anal. Calcd. for $\mathrm{C}_{41} \mathrm{H}_{29} \mathrm{NPS}_{3} \mathrm{~V}: \mathrm{C}, 68.99$; H, 4.10; N, 1.96. Found: C, 68.89; H, 4.26; N, 1.94. UV-vis (THF, $\left.298 \mathrm{~K}, \mathrm{~nm}\left\{\mathrm{~cm}^{-1} \mathrm{M}^{-1}\right\}\right): 464\{4800\}$. 
Quantification of $\mathrm{H}_{2}$ from the protonation of compound $\boldsymbol{8}$

A solution of $\left[\mathrm{H}\left(\mathrm{OEt}_{2}\right)\right]\left[\mathrm{BAr}^{\mathrm{F}}\right]$ in $\mathrm{Et}_{2} \mathrm{O}(2.4 \mathrm{mM}, 1.0 \mathrm{~mL})$ was added dropwise to a stirring solution of 8 in $\mathrm{Et}_{2} \mathrm{O}(1.2 \mathrm{mM}, 2.0 \mathrm{~mL})$ in a septum-sealed round bottom, yielding a dark red solution. The solution was stirred at $25^{\circ} \mathrm{C}$ for $10 \mathrm{~min}$, then an aliquot of the headspace was sampled and analyzed for $\mathrm{H}_{2}$ by GC. Yield of $\mathrm{H}_{2}: 91 \%$

NMR spectra

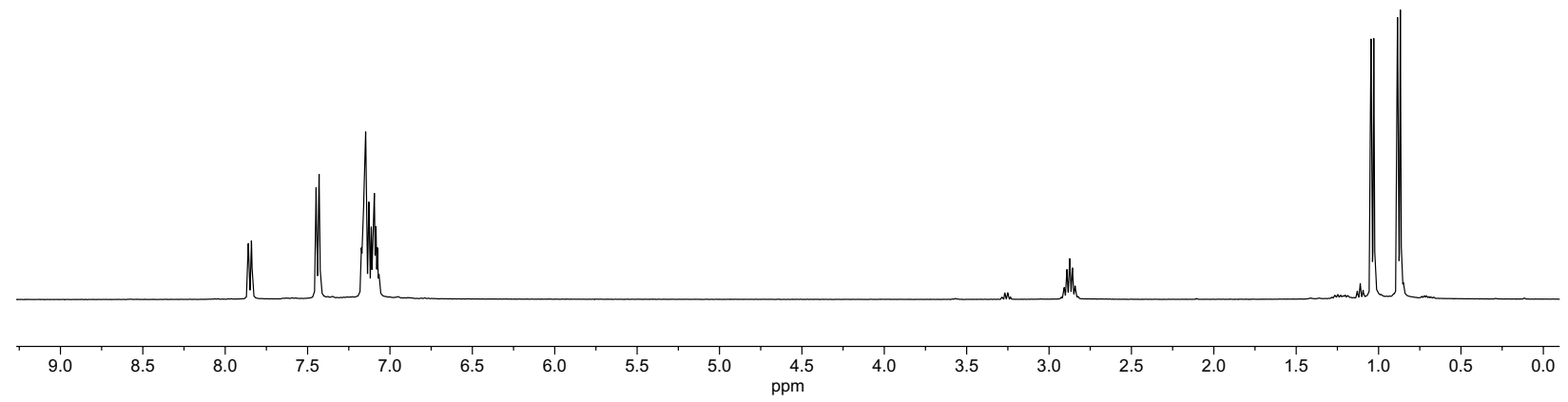

Figure S1. ${ }^{1} \mathrm{H}$ NMR spectrum of 3 in $\mathrm{C}_{6} \mathrm{D}_{6}(400 \mathrm{MHz})$

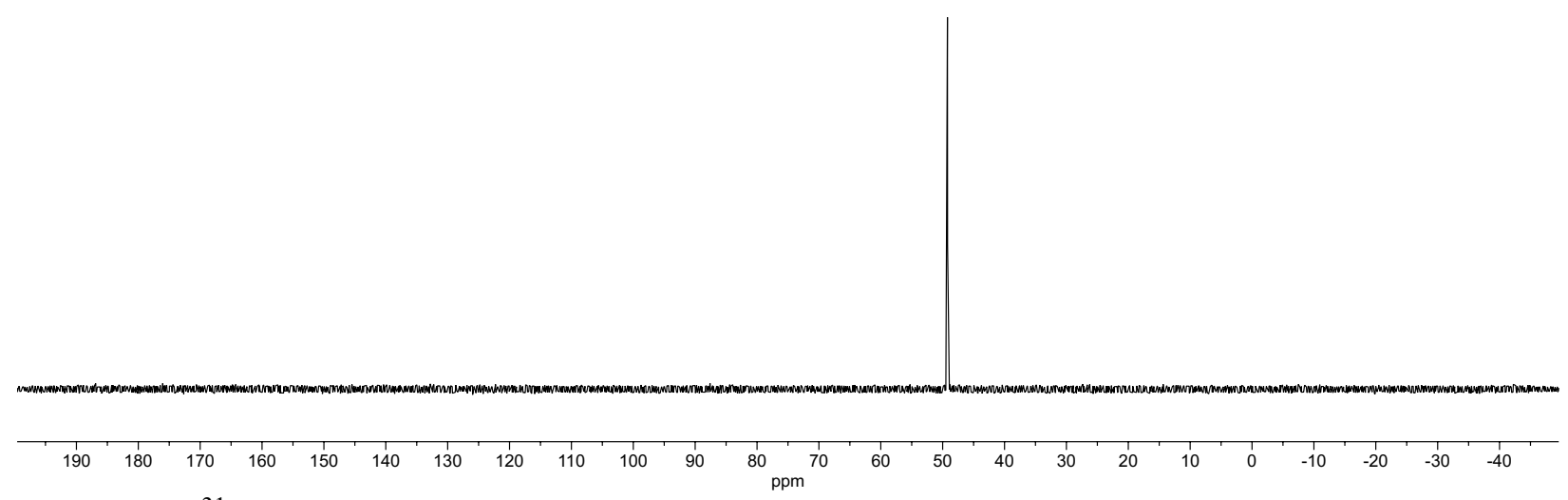

Figure S2. ${ }^{31} \mathrm{P}$ NMR spectrum of 3 in $\mathrm{C}_{6} \mathrm{D}_{6}(162 \mathrm{MHz})$ 

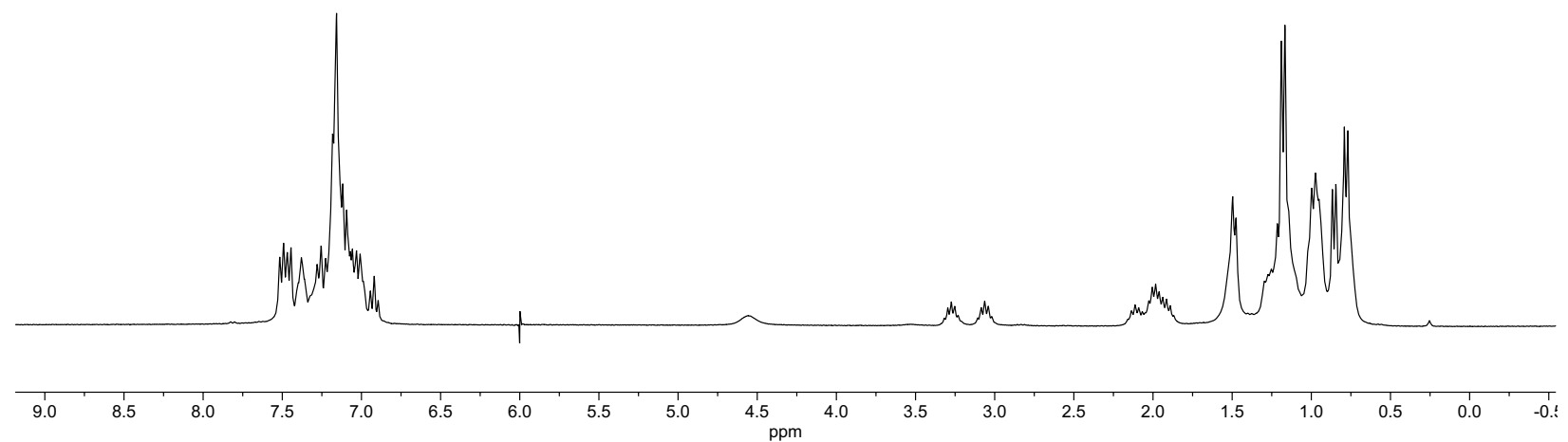

Figure S3. ${ }^{1} \mathrm{H}$ NMR spectrum of 4 in $\mathrm{C}_{6} \mathrm{D}_{6}(300 \mathrm{MHz})$

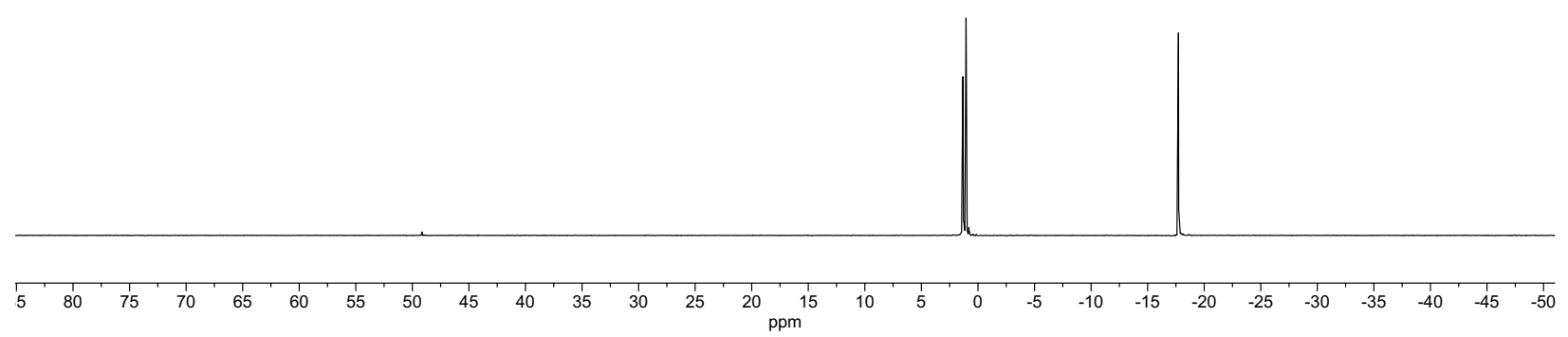

Figure S4. ${ }^{31} \mathrm{P}$ NMR spectrum of 4 in $\mathrm{C}_{6} \mathrm{D}_{6}(162 \mathrm{MHz})$

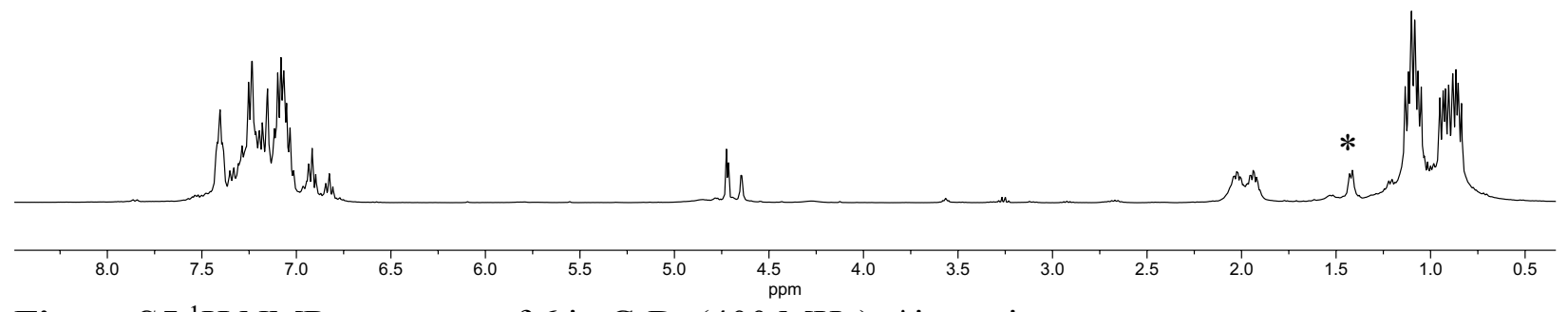

Figure S5 ${ }^{1} \mathrm{H}$ NMR spectrum of 6 in $\mathrm{C}_{6} \mathrm{D}_{6}(400 \mathrm{MHz})$. *impurity 


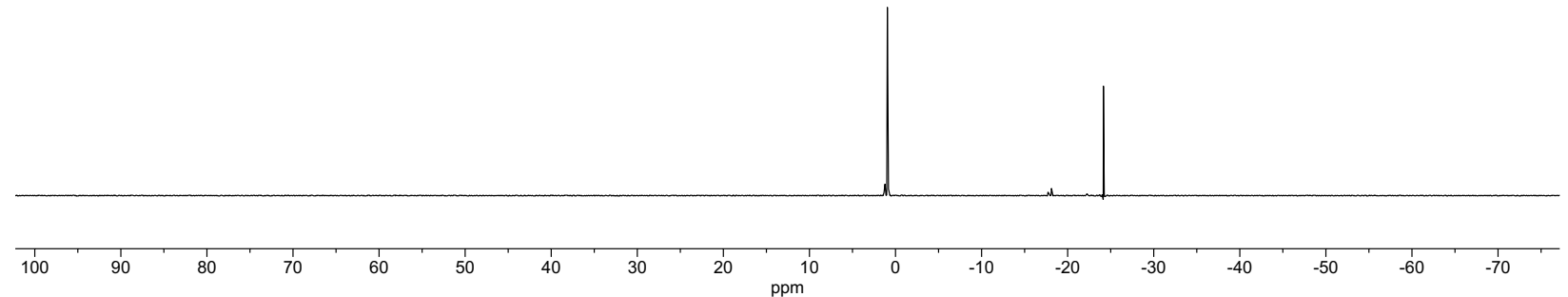

Figure S6. ${ }^{31} \mathrm{P}$ NMR spectrum of 6 in $\mathrm{C}_{6} \mathrm{D}_{6}(162 \mathrm{MHz})$

IR spectra

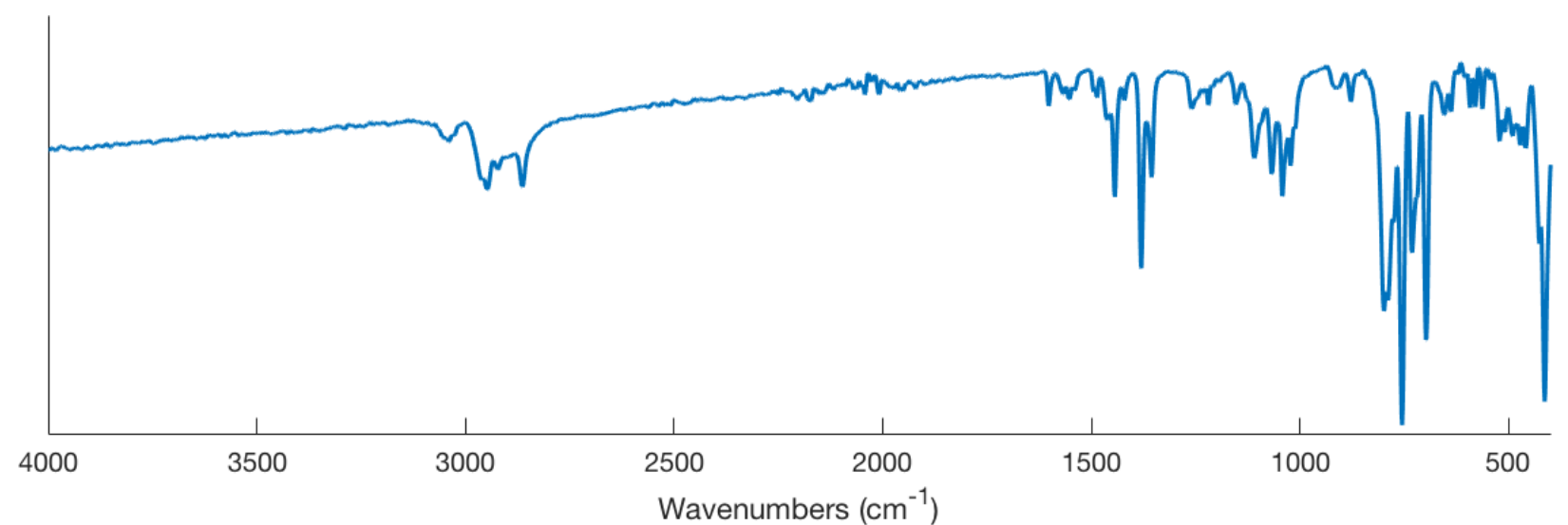

Figure S7. IR spectrum of 7 (solid sample)

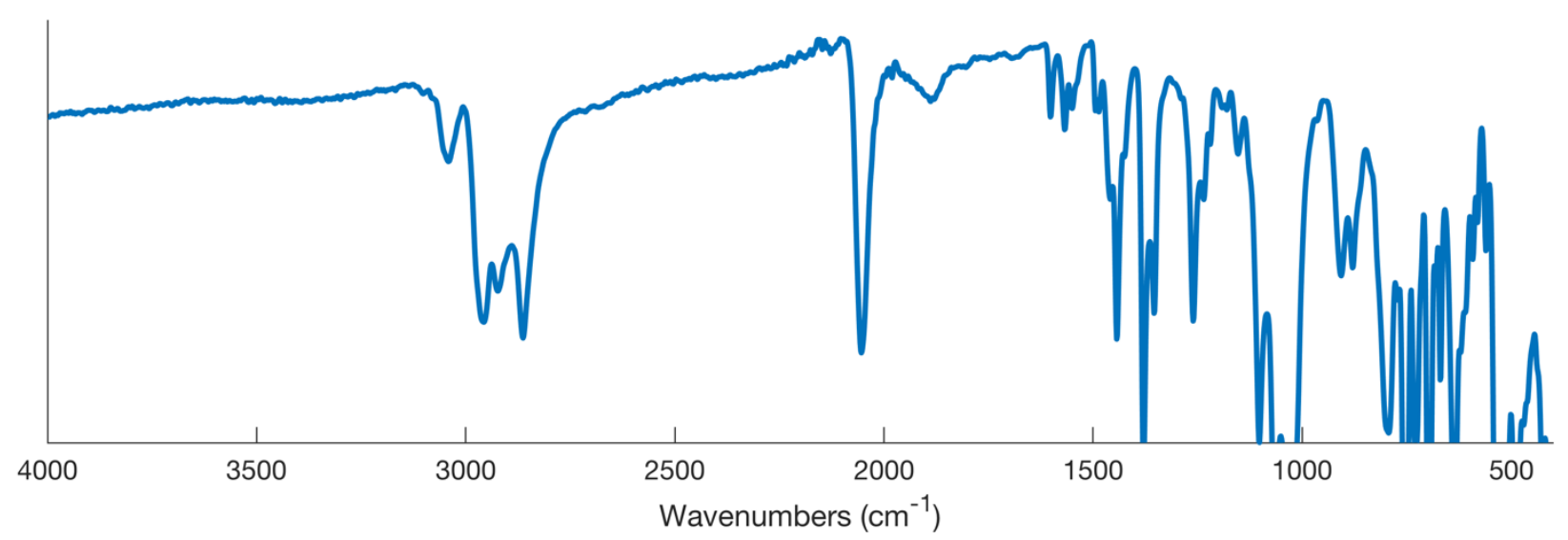

Figure S8. IR spectrum of 8 (solid sample) 


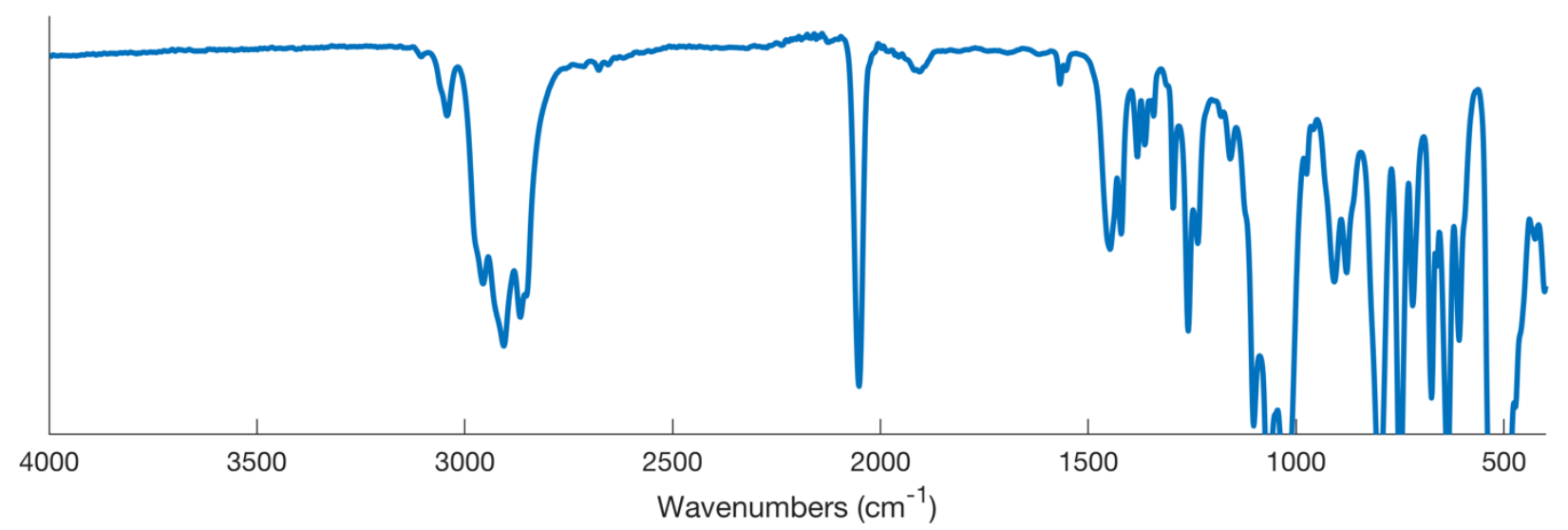

Figure S9. IR spectrum of 9 (solid sample)

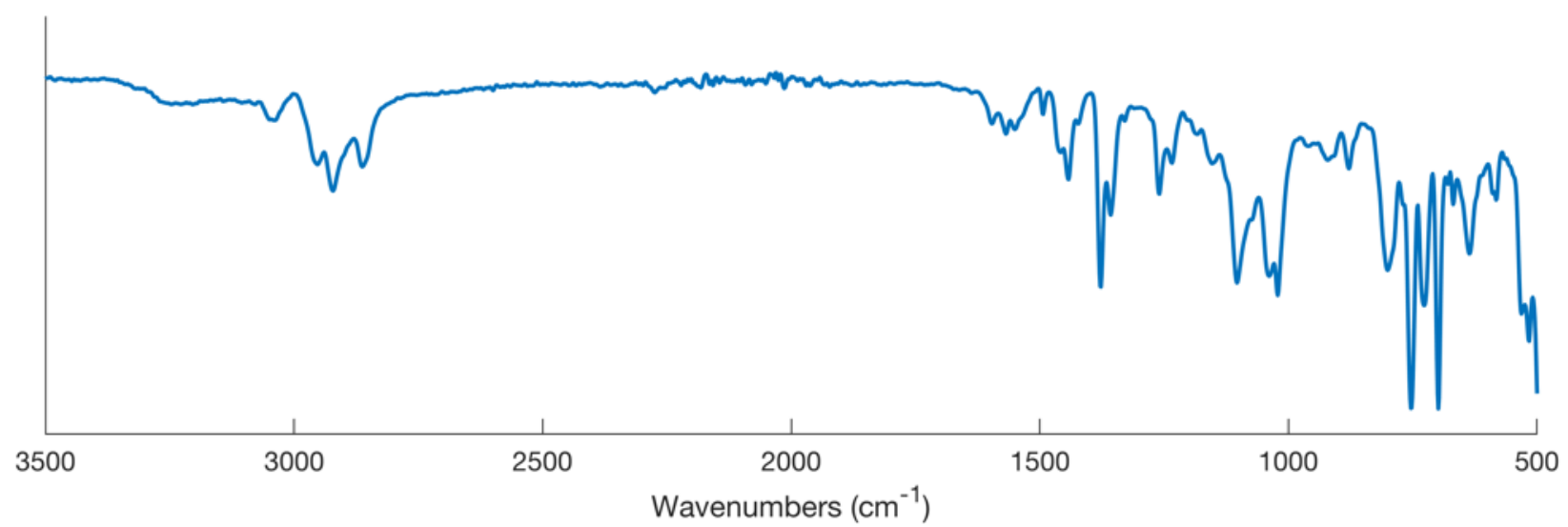

Figure S10. Representative IR spectrum of solids remaining after vacuum transfer of volatiles in a $\mathrm{N}_{2} \mathrm{H}_{4}$ disproportion catalytic run with $\mathbf{8}$ (solid sample)

UV-Visible spectra

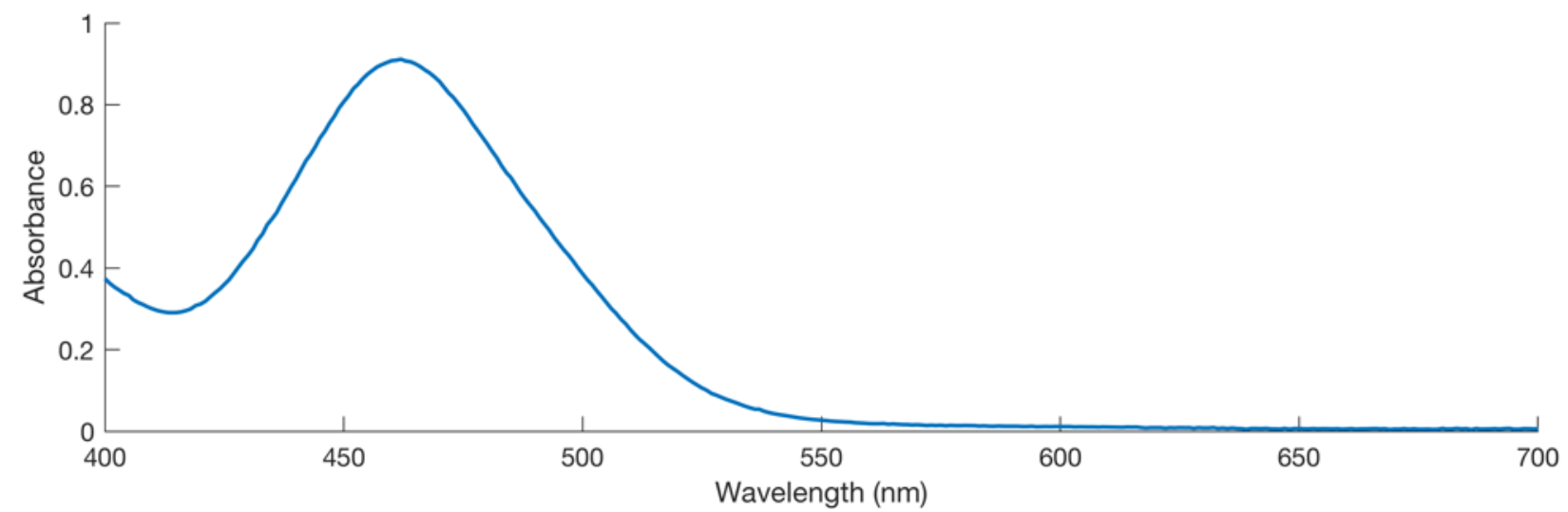

Figure S11. UV-Vis spectrum of 7 in THF 


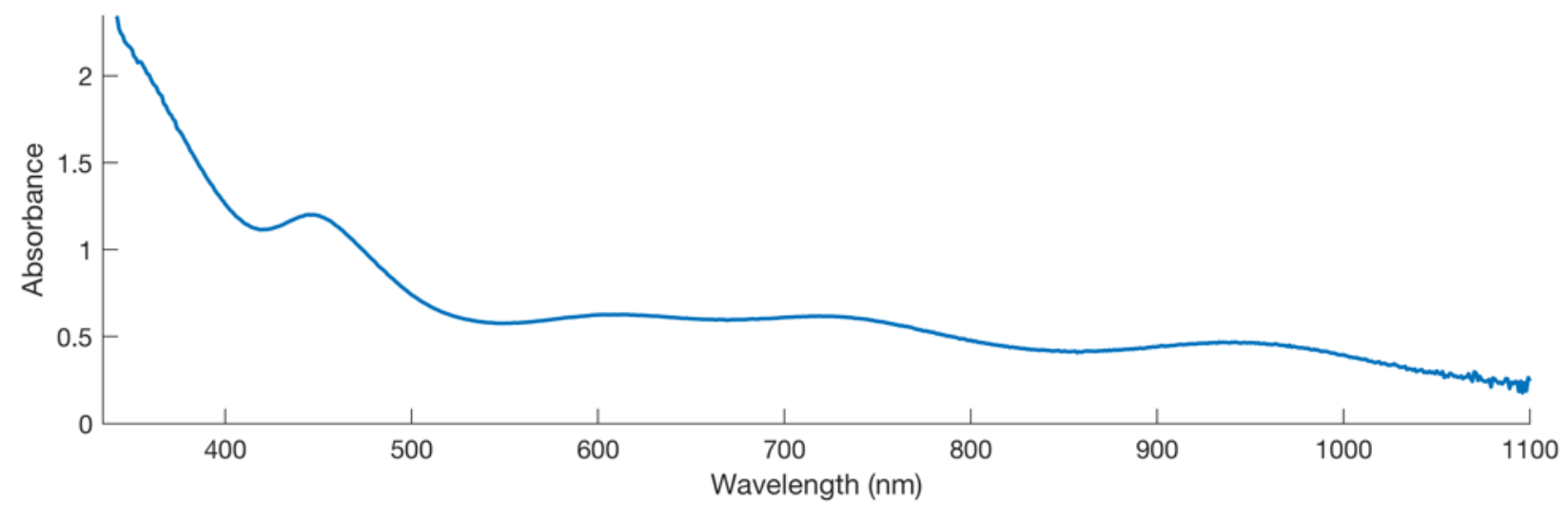

Figure S12. UV-Vis spectrum of 8 in THF

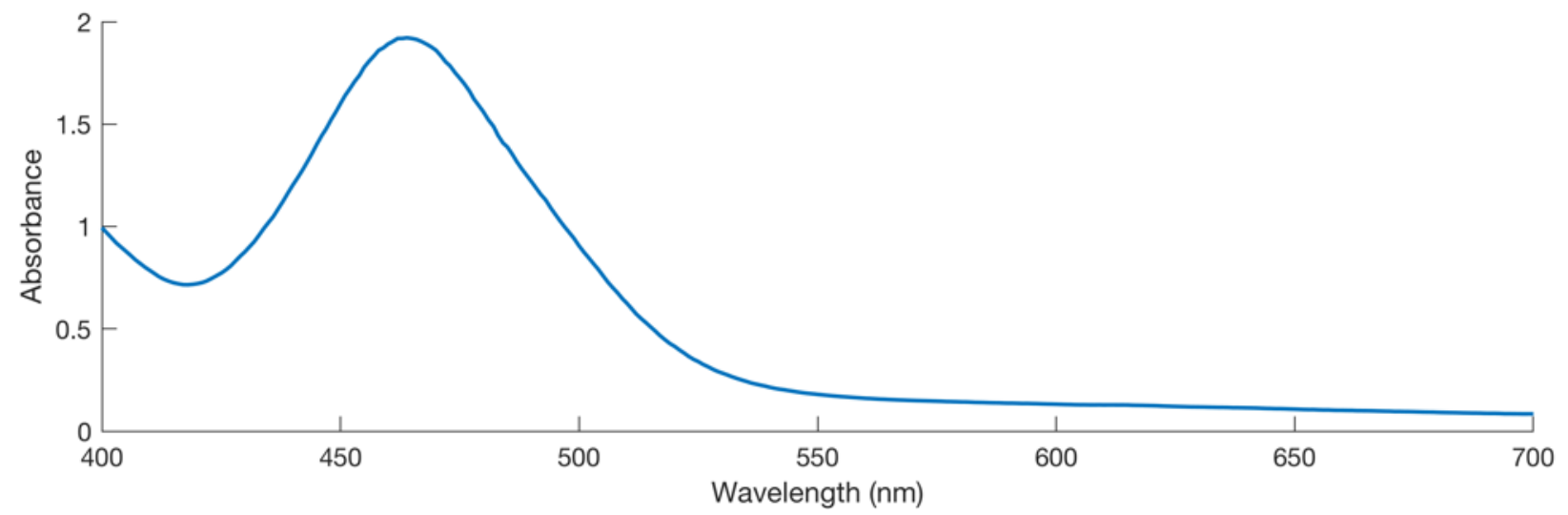

Figure S13. UV-Vis spectrum of $\mathbf{1 1}$ in THF

$X$-ray diffraction data

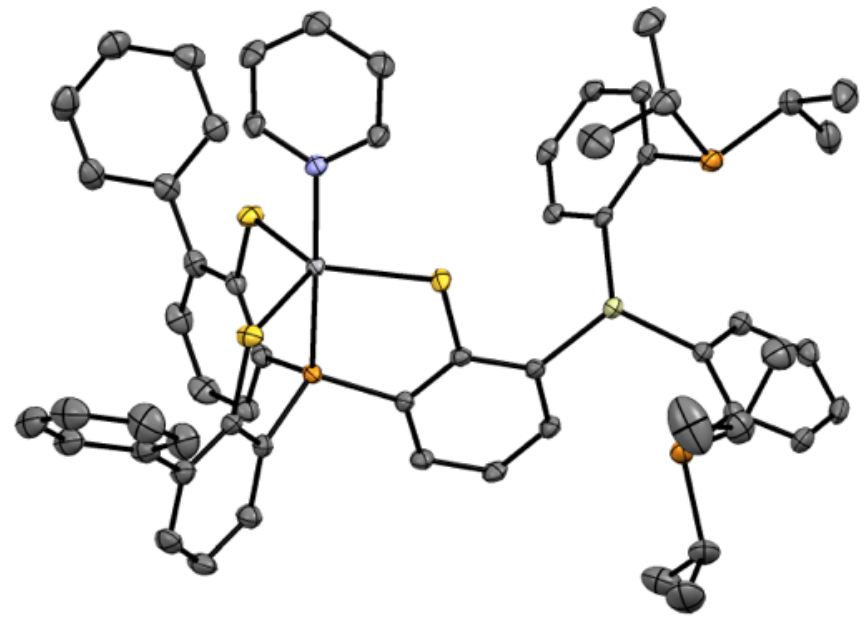

Figure S14. Structure of 7 with omission of hydrogen atoms and solvent molecules. Thermal ellipsoids at $50 \%$ probability. 


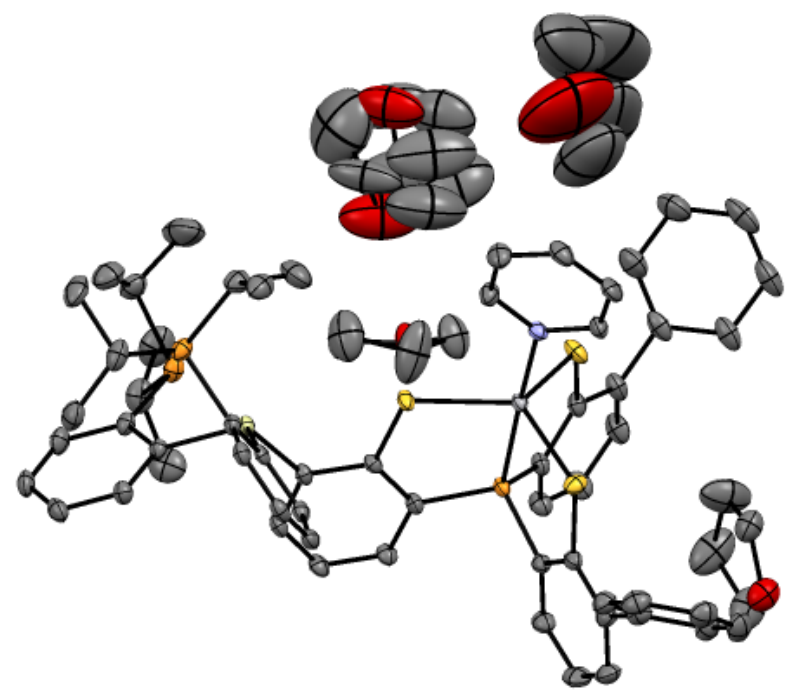

Figure S15. Full asymmetric unit of 7 including solvent and disordered components. Hydrogen atoms omitted; thermal ellipsoids at $50 \%$ probability.

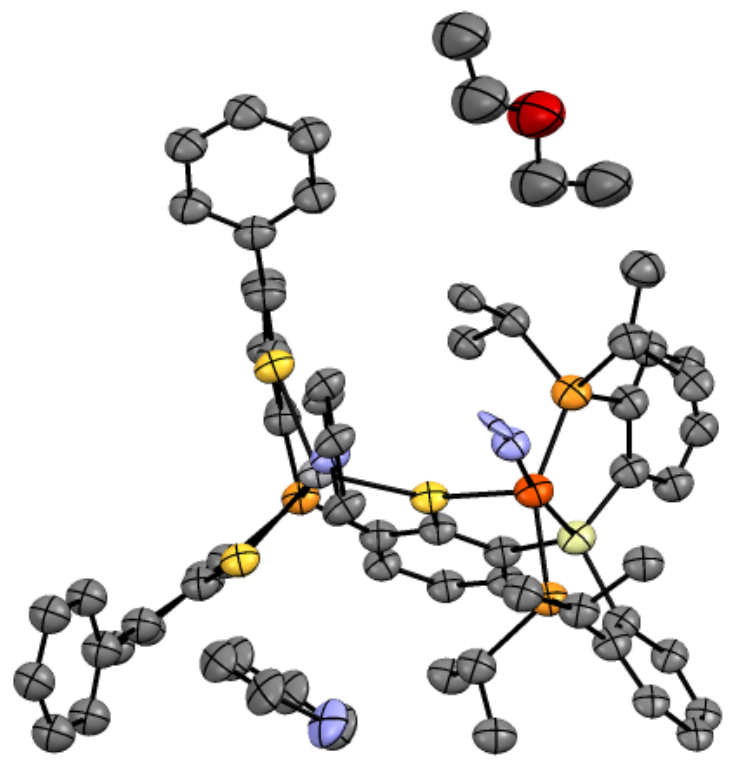

Figure S16. Full asymmetric unit of $\mathbf{8}$ including solvent. Hydrogen atoms omitted; thermal ellipsoids at $50 \%$ probability. 


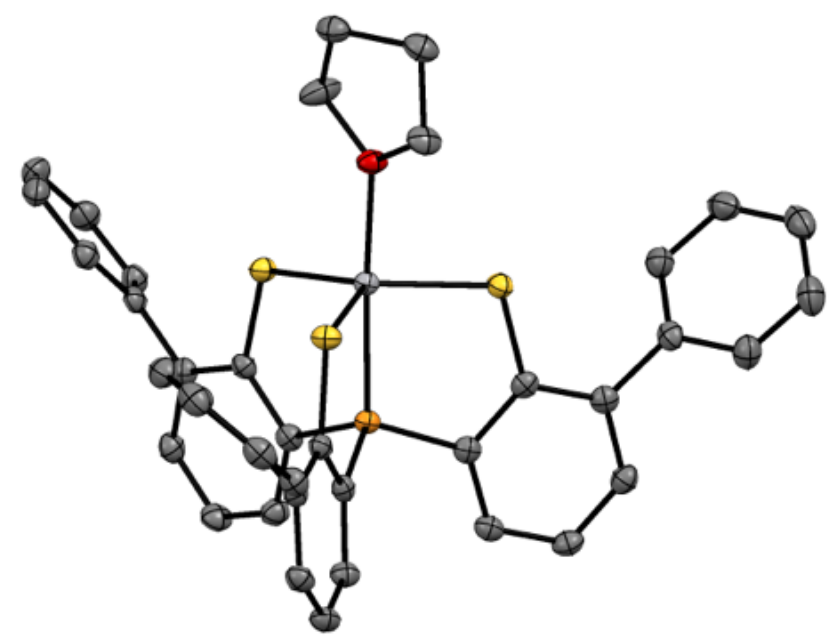

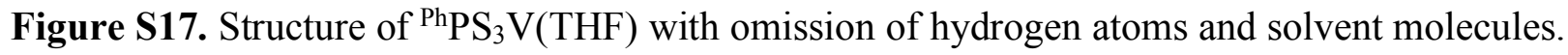
Thermal ellipsoids at 50\% probability.

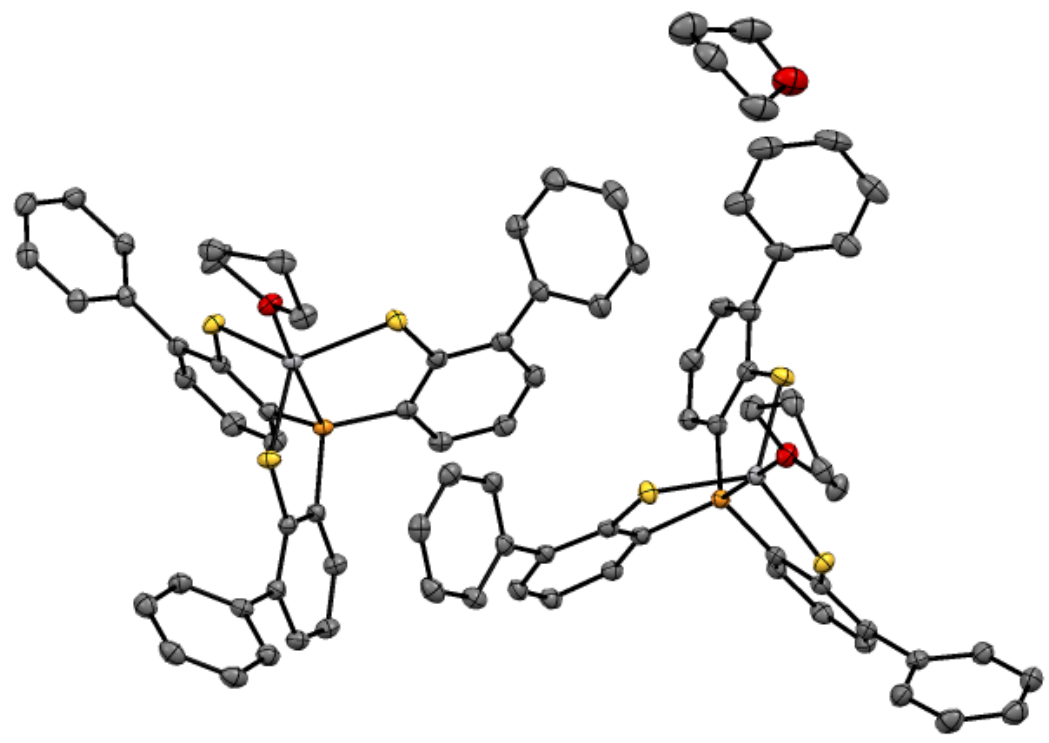

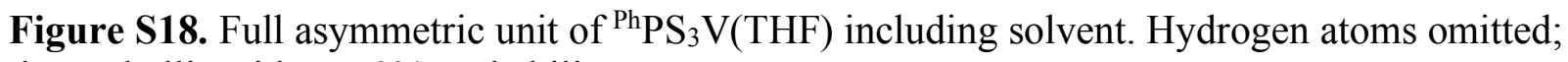
thermal ellipsoids at 50\% probability. 


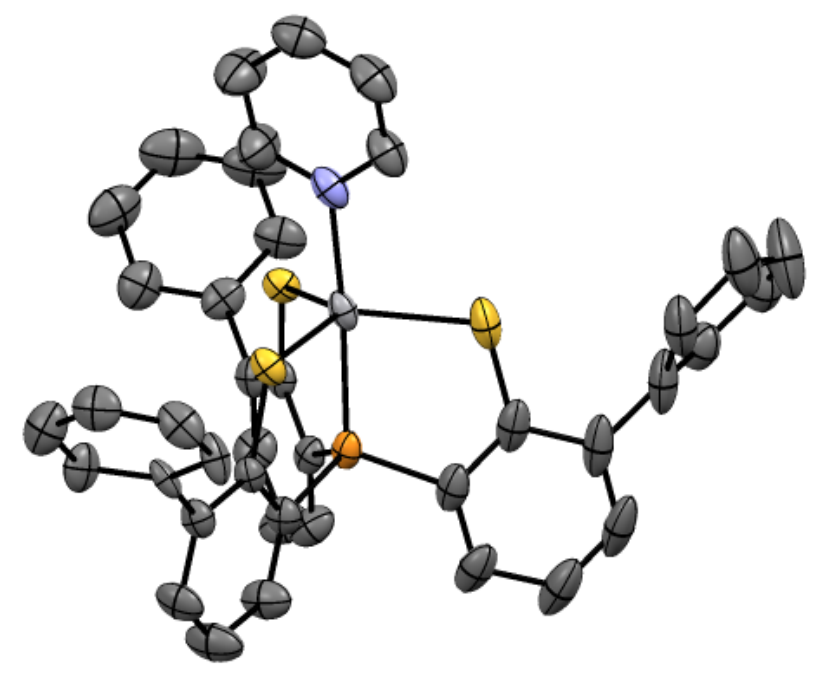

Figure S19. Structure of $\mathbf{1 1}$ with omission of disordered components and hydrogen atoms. Thermal ellipsoids at $50 \%$ probability.

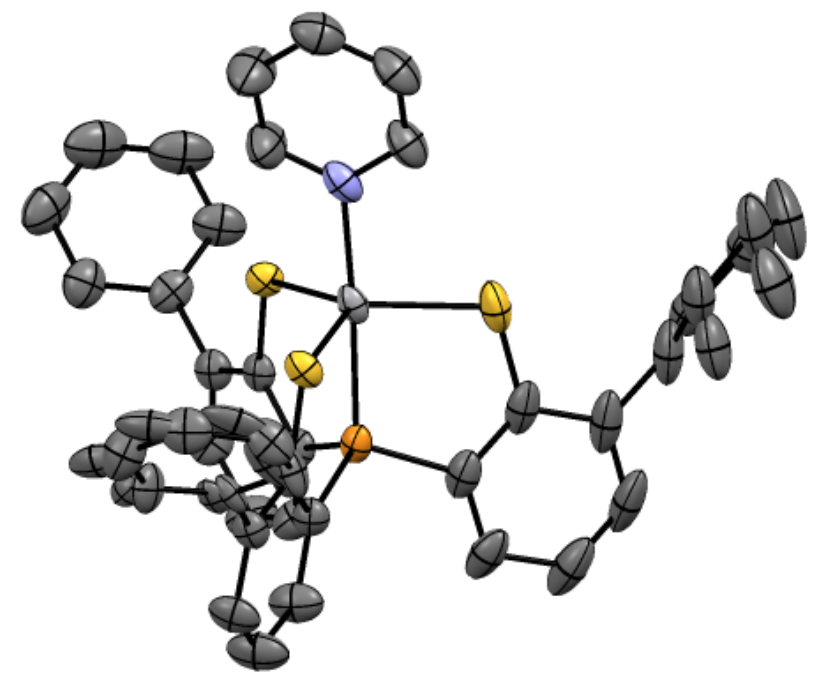

Figure S20. Full asymmetric unit of $\mathbf{1 1}$ including solvent and disordered components. Hydrogen atoms omitted; thermal ellipsoids at $50 \%$ probability. 
General procedure for catalytic hydrazine disproportionation

*Caution: All catalytic runs were performed on small scales to avoid a significant buildup of pressure from gas generated during catalysis*

A solution of catalyst ( $1 \mathrm{mM}$ catalyst, $2.5 \mathrm{~mL}$ solvent, unless otherwise noted) is transferred into a Schlenk tube and frozen. Neat $\mathrm{N}_{2} \mathrm{H}_{4}$ is added in one portion to the vessel, which is then immediately sealed and allowed to stir at $25^{\circ} \mathrm{C}$. After the appropriate amount of time elapsed, the volatiles are vacuum transferred into a Schlenk tube containing $\mathrm{HCl}\left(2 \mathrm{M}\right.$ in $\left.\mathrm{Et}_{2} \mathrm{O}, 5 \mathrm{~mL}\right)$, which is analyzed for ammonia content (in the form of $\left[\mathrm{NH}_{4}\right][\mathrm{Cl}]$ ) by the indophenol method. ${ }^{8}$ (Note: Upon thawing of the evacuated frozen vessels, care is taken to allow the vacuum transfer to proceed at $25^{\circ} \mathrm{C}$. Hydrazine is a thermally-sensitive compound, and heating a vessel containing solely $\mathrm{N}_{2} \mathrm{H}_{4}$ in THF during the work-up results in positive ammonia detection)

Single runs from Table 1

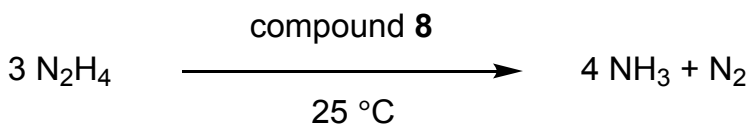

\begin{tabular}{ccccc} 
Entry & Solvent & Time & $\mathrm{N}_{2} \mathrm{H}_{4}$ (equiv./8) & $\mathrm{NH}_{3}$ (equiv./8) \\
\hline$a$ & $\mathrm{THF}$ & $2 \mathrm{~h}$ & 50 & $4.0,5.5$ \\
$b$ & $\mathrm{Et}_{2} \mathrm{O}$ & $2 \mathrm{~h}$ & 50 & $9.7,11$ \\
$c$ & $\mathrm{Et}_{2} \mathrm{O}$ & $12 \mathrm{~h}$ & 50 & 41,50 \\
$d$ & $\mathrm{Et}_{2} \mathrm{O}$ & $24 \mathrm{~h}$ & 50 & 57,62 \\
$e$ & $\mathrm{Et}_{2} \mathrm{O}$ & $24 \mathrm{~h}$ & 100 & 80,98 \\
$f$ & $\mathrm{Et}_{2} \mathrm{O}$ & $48 \mathrm{~h}$ & 100 & 102,124 \\
$g^{1}$ & $\mathrm{Et}_{2} \mathrm{O}$ & $17 \mathrm{~d}$ & 1440 & 1014,1132 \\
$S I^{*}$ & $\mathrm{Et}_{2} \mathrm{O}$ & $12 \mathrm{~h}$ & 50 & 46 \\
$S 2^{\ddagger}$ & $\mathrm{Et}_{2} \mathrm{O}$ & $12 \mathrm{~h}$ & 50 & 42 \\
$S 3^{\#}$ & $\mathrm{Et}_{2} \mathrm{O}$ & $12 \mathrm{~h}$ & 50 & 39
\end{tabular}

Runs performed at catalyst concentrations of $1 \mathrm{mM}$ in $2.5 \mathrm{~mL}$ solvent. ${ }^{1}$ Run performed with at $0.1 \mathrm{mM}$ catalyst concentration in $2.5 \mathrm{~mL}$ solvent. *Performed in the presence of elemental $\mathrm{Hg}$. *Performed in the presence of 0.3 equivalents of $\mathrm{PPh}_{3}$ per equivalent of $\mathbf{8}\left(1 \mathrm{mM}\right.$ in $\left.2 \mathrm{~mL} \mathrm{Et}_{2} \mathrm{O}\right)$. ${ }^{\#}$ Performed in the presence of 10 equivalents of pyridine per equivalent of $\mathbf{8}\left(1 \mathrm{mM}\right.$ in $\left.2 \mathrm{~mL} \mathrm{Et}_{2} \mathrm{O}\right)$.

Single runs from Table 2

$$
3 \mathrm{~N}_{2} \mathrm{H}_{4} \underset{\text { THF, } 2 \mathrm{~h}, 25^{\circ} \mathrm{C}}{\stackrel{2 \% \text { catalyst }}{\longrightarrow}} 4 \mathrm{NH}_{3}+\mathrm{N}_{2}
$$

\begin{tabular}{ccc} 
Entry & Catalyst & $\mathrm{NH}_{3}$ (equiv./catalyst) \\
\hline$h$ & $\mathbf{9}$ & $0.26,0.51$ \\
$i$ & $\mathbf{1 1}$ & $0.27,0.13$ \\
$j^{*}$ & $\mathbf{9 + 1 1}$ & $0.88,1.19$
\end{tabular}

Runs performed at catalyst concentrations of $1 \mathrm{mM}$ in $2.5 \mathrm{~mL}$ solvent. $*[\mathbf{9}]=[\mathbf{1 1}]=1 \mathrm{mM}$ 


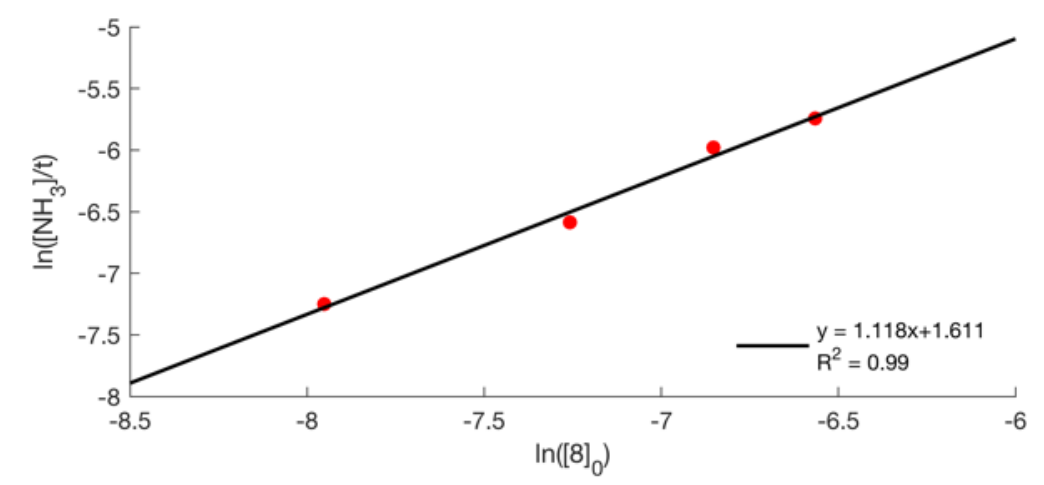

\begin{tabular}{cccc}
$\mathbf{8}(\mathrm{mg})$ & $\mathrm{NH}_{3}(\mu \mathrm{mol})$ & $\ln \left([\mathbf{8}]_{0}\right)^{1}$ & $\ln \left(\left[\mathrm{NH}_{3}\right] / \mathrm{t}\right)^{1}$ \\
\hline 1 & $3.5,3.6$ & -8.0 & -7.3 \\
2 & $5.7,8.1$ & -7.3 & -6.6 \\
3 & $12.2,13.1$ & -6.9 & -6.0 \\
4 & $16.0,16.1$ & -6.6 & -5.7
\end{tabular}

Runs performed with $0.13 \mathrm{mmol} \mathrm{N}_{2} \mathrm{H}_{4}$ in $2.5 \mathrm{~mL}$ THF. Yield of $\mathrm{NH}_{3}$ determined after $2 \mathrm{~h}$ of reaction time. ${ }^{1}$ concentrations in $\mathrm{M}$, time in $\mathrm{h}$

Reaction order of substrate - method of initial rates

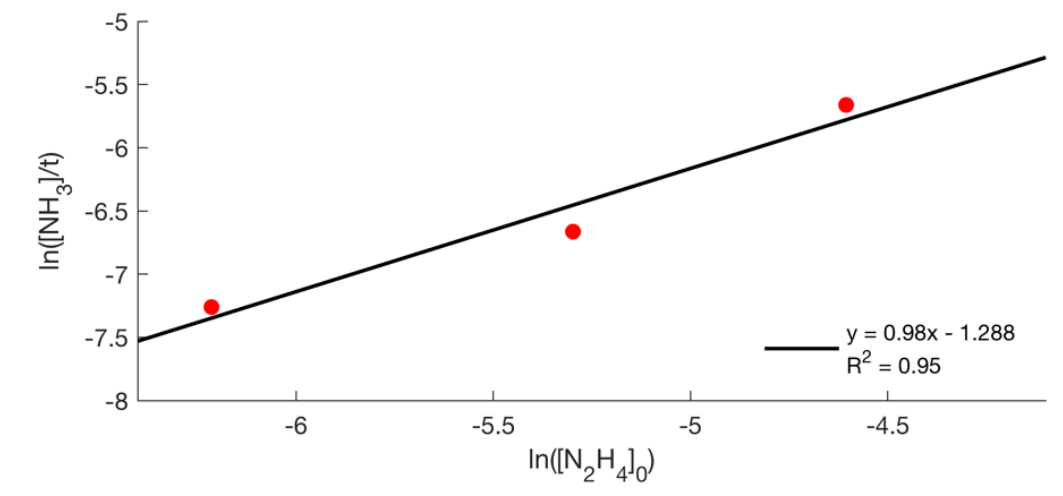

\begin{tabular}{cccc}
{$\left[\mathrm{N}_{2} \mathrm{H}_{4}\right]$} & $\mathrm{NH}_{3}(\mu \mathrm{mol})$ & $\ln \left(\left[\mathrm{N}_{2} \mathrm{H}_{4}\right]_{0}\right)^{1}$ & $\ln \left(\left[\mathrm{NH}_{3}\right] / \mathrm{t}\right)^{1}$ \\
\hline 0.002 & $0.23,0.24$ & -6.2 & -7.3 \\
0.005 & $0.39,0.46$ & -5.3 & -6.7 \\
0.010 & $0.97,1.4$ & -4.6 & -5.7
\end{tabular}

Runs performed in $2 \mathrm{~mL}$ THF with $1 \mathrm{mM}$ catalyst (a THF solution of substrate is added at $25^{\circ} \mathrm{C}$ to a Schlenk tube containing a stirring THF solution of catalyst and immediately sealed). Yield of $\mathrm{NH}_{3}$ determined after 10 min of reaction time. ${ }^{1}$ concentrations in $\mathrm{M}$, time in $\mathrm{h}$ 
Reaction order of substrate - method of initial rates (saturation kinetics)

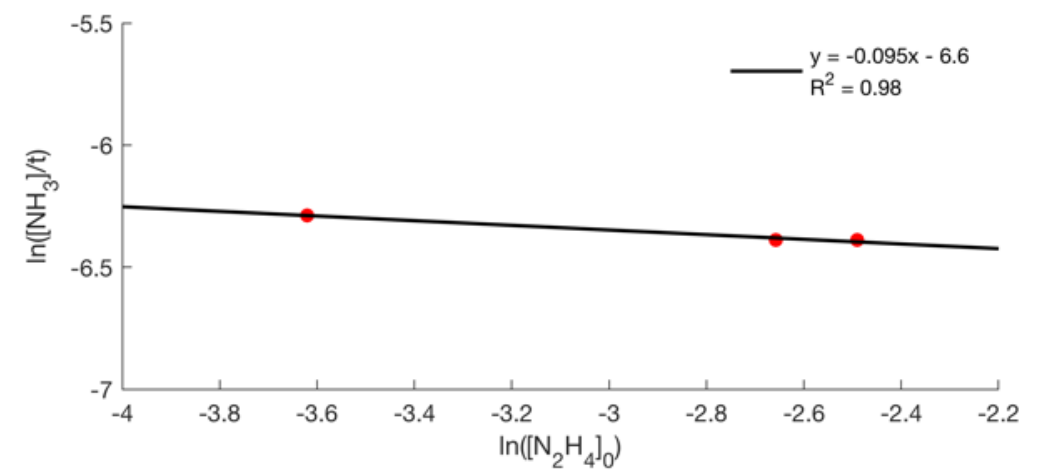

\begin{tabular}{cccc}
{$\left[\mathrm{N}_{2} \mathrm{H}_{4}\right]$} & $\mathrm{NH}_{3}(\mu \mathrm{mol})$ & $\ln \left(\left[\mathrm{N}_{2} \mathrm{H}_{4}\right]_{0}\right)^{1}$ & $\ln \left(\left[\mathrm{NH}_{3}\right] / \mathrm{t}\right)^{1}$ \\
\hline 0.025 & $9.0,9.6$ & -3.6 & -6.3 \\
0.070 & $7.9,8.8$ & -2.7 & -6.4 \\
0.083 & $8.3,8.5$ & -2.5 & -6.4
\end{tabular}

Runs performed in $2.5 \mathrm{~mL}$ THF with $1 \mathrm{mM}$ catalyst. Yield of $\mathrm{NH}_{3}$ determined after $2 \mathrm{~h}$ of reaction time.

${ }^{1}$ concentrations in $\mathrm{M}$, time in $\mathrm{h}$

\section{Toepler pump quantification of gaseous products}

Neat $\mathrm{N}_{2} \mathrm{H}_{4}(0.1 \mathrm{mmol})$ was added in one portion at $25^{\circ} \mathrm{C}$ to a stirring $\mathrm{Et}_{2} \mathrm{O}$ solution of $8(2.4 \mathrm{mg}$, $0.002 \mathrm{mmol}$ ) in a $100 \mathrm{~mL}$ Kontes Schlenk tube equipped with a ground-glass side arm. The tube was degassed via three freeze-pump-thaw cycles and sealed. The reaction mixture stirred at $25^{\circ} \mathrm{C}$ under static vacuum. The volatiles in the tube were passed through a cold trap $(77 \mathrm{~K})$, and the noncondensed gaseous products were quantified with a Toepler pump. The frozen volatiles condensed in the traps were vacuum transferred into a Schlenk tube containing an ethereal solution of $\mathrm{HCl}(5$ $\mathrm{mL}, 2 \mathrm{M}$ ) and concentrated to dryness. The resulting material was quantified for ammonia (in the form of $[\mathrm{NH} 4][\mathrm{Cl}]$ ) via the indophenol method. ${ }^{8}$ Omitting the equivalent of $\mathrm{N}_{2}$ that is introduced from 8, 4.0 molecules of $\mathrm{NH}_{3}$ per gas molecule was generated.

${ }^{1}$ P. L. McGinley, J. T. Koh, J. Am. Chem. Soc. 2007, 129, 3822.

${ }^{2}$ V. W. Seidel, G. Kreisel Z. anorg. allg. Chem. 1977, 435, 146.

${ }^{3}$ T. K. A. Hoang, A. Hamaed, G. Moula, R. Aroca, M. Trudeau, D. M. Antonelli J. Am. Chem. Soc. 2011, 133, 4955.

${ }^{4}$ J.-C. Tsai, Masters thesis, Stony Brook University, 2011.

${ }^{5}$ N. X., Gu, P. H. Oyala, J. C. Peters, J. Am. Chem. Soc. 2018, 140, 6374.

${ }^{6}$ S. E. Creutz, J. C. Peters, J. Am. Chem. Soc. 2015, 137, 7310.

${ }^{7}$ A. Takaoka, N. P. Mankad, J. C. Peters, J. Am. Chem. Soc. 2011, 133, 8440.

${ }^{8}$ M. W. Weatherburn, Anal. Chem. 1967, 39, 971. 